origin in the rat of la-positive cells with dendritic morphology and of Ia antigen in epithelia, with special reference to the intestine. Eur $\mathrm{J}$ Immunol 13:112-122

27. MacDonald TT, Weinel A, Spencer J 1988 HLA-DR expression in fetal intestinal epithelium. Gut 29:1342-1348

28. Oliver AM, Thomson AW, Sewell HF, Abramovich DR 1988 Major histocompatibility complex (MHC) class II antigen (HLA-DR, DQ, and DP) expres- sion in human fetal endocrine organs and gut. Scand J Immunol 27:731737

29. Kvale D, Brandtzaeg P, Løvhaug D 1988 Up-regulation of the expression of secretory component and HLA molecules in a human colonic cell line by tumour necrosis factor- $\alpha$ and gamma interferon. Scand J Immunol 28:351357

\title{
Announcement
}

\section{World Congress on Rett Syndrome}

The World Congress on Rett Syndrome will be held October 7-10, 1993 in Antwerp, Belgium. Parents, physicians, psychologists, therapists, and teachers are invited to participate in the congress. For further information, contact Vanherck Peter, Lil 26, B-2450 Meerhout, Belgium, Fax: 32014303157. 